the publication of clinical data on provider organisations. On the whole, these studies have found that published clinical indicators rarely stimulate quality improvement. ${ }^{1-3} 7$ Our findings indicate several reasons why published clinical indicators often have little or no effect in provider organisations. A key lesson of the Scottish experience is that those responsible for designing clinical indicator systems should not only concentrate on developing robust datasets with but should also encourage a suitable organisational environment and incentive context to foster the use of these data for continuous quality improvement.

We thank the interviewees, who without exception readily gave up their valuable time to share with us their knowledge of the CRAG indicators. We are grateful to Peter Smith and Huw Davies for their comments on an earlier draft of this paper. We also thank David Clyne and Steve Kendrick for their assistance with this project.

Contributors: RM was principal investigator and is guarantor of the paper. RM and MG designed the study. RM conducted the interviews and performed the preliminary qualitative analysis. MG read a sample of interview transcripts and helped to interpret the data. Both authors contributed towards the final paper.

Funding: Department of Health as part of a core programme of work on performance management at the Centre for Health Economics, University of York. The views expressed in this paper are those of the authors and not necessarily those of the Department of Health.

Competing interests: None declared.

1 Marshall M, Shekelle P, Leatherman S, Brook R. Public disclosure of performance data: learning from the US experience. Qual Health Care 2000;9:53-7.

\section{What is already known on this topic}

Current policy on performance assessment in England and Wales places a great deal of emphasis on the collection and dissemination of clinical information

Dissemination of clinical outcome data has had limited impact on the behaviour of provider organisations in the United States

\section{What this paper adds}

Research in Scottish trusts suggests that clinical indicators are rarely used to stimulate quality improvement or share good practice

The reasons for low impact include internal factors relating to the properties of the indicators and external factors within the organisational environment in which the data are used

2 Marshall M, Shekelle P, Leatherman S. Public reporting of performance: lessons from the USA. J Health Serv Res Policy 2000;5:1-2.

3 Marshall M, Shekelle P, Leatherman S, Brook R. What do we expect to gain from the public release of performance data? A review of the evidence. JAMA 2000;283:1866-74.

4 Kendrick S, Cline D, Finlayson A. Clinical outcome indicators in Scotland: lessons and prospects. In: Davies H, Malek M, Nielson A, Tavolaki M, eds. Managing quality and controlling costs. Aldershot: Ashgate Publishing, 1999.

5 Carstairs V, Morris R. Deprivation and health in Scotland. Aberdeen: Aberdeen University, 1991.

6 Banister P, Burman E, Parker I, Taylor M, Tindall C. Qualitative research methods in psychology: a research guide. Buckingham: Open University Press, 1994.

7 Rainwater J, Romano P, Antonius D. The Californian hospital outcome project: how useful is California's report card for quality improvement? $J$ Comm J Qual Improv 1999;24:31-9.

(Accepted 13 June 2001)

\title{
Declaring financial competing interests: survey of five general medical journals
}

Amina Hussain, Richard Smith

Although many authors of biomedical journal articles have financial competing interests, they often fail to disclose them. ${ }^{1-3}$ Editors have been concerned about this for a long time. In 1985, the International Committee of Medical Journal Editors produced a statement on conflicts of interest, and journal editors adopted individual policies. ${ }^{4}$ But how effective have their policies been in practice?

Krimsky et al investigated the financial interests of over 1000 authors whose articles appeared in 14 scientific and medical journals in $1992 .^{3}$ Although $15 \%$ of authors had financial ties relevant to one of their publications, no voluntary disclosures were published. In 1998, Stelfox et al showed that 23/24 authors (96\%) defending the safety of calcium channel antagonists had financial ties with manufacturers of these drugs compared with 11/30 (37\%) who were critical of their use. $^{1}$ Only $2 / 70$ articles disclosed the authors' potential conflicts of interest. These findings confirmed that little had been achieved since initial concerns had been raised over a decade earlier. Recently, however, editors have been paying more attention to the issue and urging authors to declare competing interests. This study aimed to find out whether more authors have been doing this.

\section{Methods and results}

Using random number tables, we selected six sample issues of five leading medical journals (Annals of Internal Medicine, BMJ, JAMA, Lancet, and New England Journal of Medicine) from each of four years: 1989, 1994, 1996, and 1999. All editorials, papers reporting original research, and letters were examined to see if they contained a statement declaring authors' potential financial competing interests (this did not include statements that only mentioned the funding source). We also examined each journal's written policy on financial competing interests (see the BMJ's website).

We studied 3642 articles, 52 (1.4\%) of which declared authors' competing interests: two articles in 1989, eight in 1994, four in 1996, and 38 in 1999. The papers section had the greatest proportion of declarations $(23 / 656 ; 3.5 \%)$, followed by editorials $(7 / 412$; $1.7 \%)$, then letters $(22 / 2574 ; 0.9 \%)$ (table).

\section{Comment}

After much delay, there are now signs of a small, but increasing, proportion of articles declaring competing interests in some journals. Variations in policy require-
$B M J$, London WC1H 9JR

Amina Hussain

Clegg scholar

Richard Smith

editor

Correspondence to: A Hussain,

Raigmore Hospital, Inverness IV2 3UJ hussainamina@

hotmail.com

BMJ 2001;323:263-4

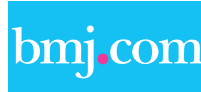

Written policies on each of the five journals are available on the BMJ's website 
Proportion of articles in five medical journals with financial competing interest statements. Values are numbers (percentages)

\begin{tabular}{|c|c|c|c|c|c|}
\hline Sample year & $\begin{array}{l}\text { Annals of } \\
\text { Internal } \\
\text { Medicine }\end{array}$ & BMJ & JAMA & Lancet & $\begin{array}{c}\text { New England } \\
\text { Journal of } \\
\text { Medicine }\end{array}$ \\
\hline \multicolumn{6}{|c|}{ Editorials $(n=412)$ : } \\
\hline 1989 & $0 / 13$ & $0 / 23$ & $0 / 8$ & $0 / 33$ & $0 / 14$ \\
\hline 1994 & $0 / 13$ & $0 / 33$ & $1 / 11(9)$ & $0 / 35$ & $0 / 17$ \\
\hline 1996 & $0 / 12$ & $0 / 32$ & $0 / 12$ & $0 / 40$ & $0 / 11$ \\
\hline 1999 & $1 / 10(10)$ & $2 / 30(7)$ & $3 / 11(27)$ & $0 / 40$ & $0 / 14$ \\
\hline Total & $1 / 48(2)$ & $2 / 118(2)$ & $4 / 42(10)$ & $0 / 148$ & $0 / 56$ \\
\hline \multicolumn{6}{|c|}{ Papers $(n=656)$ : } \\
\hline 1989 & $0 / 28$ & $0 / 51$ & $0 / 26$ & $0 / 26$ & 2/23 (9) \\
\hline 1994 & $0 / 39$ & $0 / 45$ & $2 / 24(8)$ & $0 / 37$ & $0 / 26$ \\
\hline 1996 & $0 / 36$ & $1 / 51(2)$ & $0 / 24$ & $0 / 34$ & $0 / 26$ \\
\hline 1999 & $0 / 33$ & $8 / 37(22)$ & $6 / 27(22)$ & $0 / 37$ & $4 / 26(15)$ \\
\hline Total & $0 / 136$ & $9 / 184(5)$ & $8 / 101(8)$ & $0 / 134$ & $6 / 101(6)$ \\
\hline \multicolumn{6}{|c|}{ Letters $(n=2574)$ : } \\
\hline 1989 & $0 / 71$ & 0/172 & $0 / 101$ & $0 / 262$ & $0 / 120$ \\
\hline 1994 & $0 / 86$ & $1 / 176(<1)$ & $4 / 82(5)$ & $0 / 211$ & $0 / 131$ \\
\hline 1996 & $0 / 66$ & $0 / 167$ & $3 / 85$ (4) & $0 / 205$ & $0 / 113$ \\
\hline 1999 & $0 / 63$ & $8 / 139(6)$ & $5 / 82(6)$ & $1 / 129(<1)$ & $0 / 113$ \\
\hline Total & $0 / 286$ & $9 / 654(1)$ & $12 / 350(3)$ & $1 / 807(<1)$ & $0 / 477$ \\
\hline
\end{tabular}

ments may account for the disparity among journals. For instance, the lack of declarations in New England Journal of Medicine editorials is not surprising as the journal (not always successfully ${ }^{2}$ ) prohibits them being written by authors with financial ties. The Lancet's in-house editorial team always writes the first editorial of each issue, signing it "The Lancet," a style that makes it impossible to know whether contributing authors have competing interests. But subsequent editorials conform to the more common format of naming individual authors at the end of the article, making it possible to request, and thus publish, details of each author's competing interests. The greater proportion of declarations in JAMA editorials may reflect the journal's longstanding policy of requiring authors to sign documents declaring any financial competing interests. The proportion of declarations in $B M J$ papers was much greater in 1999 than 1996. This may reflect the journal's adoption, in 1998, of Stelfox's recommendations requiring authors to answer a series of short questions on their financial ties. ${ }^{5}$

Data in this study have been drawn from information published in journals, and not directly from what authors revealed to editors. There is potential for disparity here, but it is difficult to see why editors would decide against revealing competing interests that were disclosed to them, given what is clearly stated in their policies.

Editors can learn much from examining the policies of other journals and adopting the features that seem conducive to disclosure. Research is needed to verify whether some of the authors who had not made a declaration did in fact have undeclared financial competing interests when they wrote their articles. It would also be useful to know the impact, if any, of competing interest statements on readers.

We thank Julie Morris for statistical advice.

Contributors: AH designed the study, collected the data, and wrote the paper. RS proposed the idea for the study, discussed the interpretation with $\mathrm{AH}$, and corrected the manuscript. $\mathrm{AH}$ is guarantor.

Funding: No additional funding.

Competing interests: RS is the editor of the $B M J$ and responsible for devising its policy on competing interests. He is paid a fixed salary and will not be affected financially by the success or failure of the policy on competing interests.

This study was peer reviewed in the normal way, except that RS played no part in the process.

1 Stelfox HT, Chua G, O'Rourke K, Detsky AS. Conflict of interest in the debate over calcium channel antagonists. N Engl J Med 1998;338:101-5.

2 Monmaney T. Medical journals may have flouted own ethics 8 times. Los Angeles Times 1999 October 21.

3 Krimsky S, Rothenberg LS, Stott P, Kyle G. Scientific journals and their authors' financial interests: a pilot study. Sci Eng Ethics 1996;2:395-410.

4 International Committee of Medical Journal Editors. Conflict of interest. Lancet 1993;341:742-3.

5 Smith R. Beyond conflict of interest. BMJ 1998;317:291-2.

(Accepted 26 March 2001)

\section{Effect of Helicobacter pylori infection on blood pressure: a community based cross sectional study}

Richard Harvey, Athene Lane, Liam Murray, Ian Harvey, Prakash Nair, Jenny Donovan

Frenchay Hospital, North Bristol NHS Trust, Bristol BS16 1LE

Richard Harvey consultant gastroenterologist

Prakash Nair special lecturer in medicine

continued over

BMJ 2001;323:264-5
Many studies have reported an association between Helicobacter pylori infection and an increased risk of cardiovascular disease. The strength of the association has been hard to judge because of the varied methods of the studies and substantial heterogeneity of the findings. Mechanisms that may contribute to this association include abnormalities in the levels of certain blood proteins (for example fibrinogen or $\mathrm{C}$ reactive protein) secondary to the chronic infection ${ }^{12}$ and raised blood pressure in people infected with H pylori..$^{3-5}$

There are several methodological difficulties in carrying out studies to determine whether $H$ pylori infection results in raised blood pressure. We have attempted to minimise such problems in a large prospective community based study of the association between $H$ pylori infection and blood pressure.

\section{Methods and results}

The Bristol helicobacter project is a community based study centred on the northeastern suburbs of Bristol. The primary aims of the study are to assess the effects of $H$ pylori infection (and its eradication, on a double blind basis) on digestive symptoms and their treatment and on various other aspects of health and quality of life. We have measured blood pressure prospectively in people who were recruited into this study and whose helicobacter status and other risk factors for raised blood pressure were known.

Of the 10537 subjects enrolled in the project, 1634 (15.5\%) were positive for $H$ pylori infection on a ${ }^{13} \mathrm{C}$ urea breath test, using $100 \mathrm{mg}^{13} \mathrm{C}$ urea with a standard orange juice and citric acid test meal and a cut off of $3.5 \delta{ }^{13} \mathrm{C}$ per ml. Blood pressure was measured with a 